\title{
Publisher Correction to EJNMMI Radiopharmacy and Chemistry Volume 1 (2016)
}

\author{
BioMed Central
}

\author{
* Correspondence: \\ https://www.biomedcentral.com/
}

The metadata in the HTML format of these original articles (Eppard et al., 2017; Decristoforo \& Patt, 2017; Domnanich et al., 2017; Chan et al., 2017; Jovalekic et al., 2017; Zhang \& Villalobos, 2017; Meckel et al., 2017; Li et al., 2017; Colin et al., 2017; Koziorowski et al., 2017; Ooms et al., 2017; Elsinga, 2017; Seemann et al., 2017; Müller et al., 2017; Luurtsema et al., 2017) were published with an incorrect cover date. The correct cover date is December 2016. This does not alter the text of the original articles.

The publisher apologises for this processing error.

Received: 11 October 2018 Accepted: 11 October 2018

Published online: 26 November 2018

\section{References}

Chan HS, de Blois E, Konijnenberg MW, Morgenstern A, Bruchertseifer F, Norenberg JP, et al. Optimizing labelling conditions of ${ }^{213} \mathrm{Bi}$-DOTATATE for preclinical applications of peptide receptor targeted alpha therapy. Ejnmmi Radiopharm Chem. 2017;1 (1):9 https://doi.org/10.1186/s41181-016-0014-4.

Colin DJ, Inkster JAH, Germain S, Seimbille Y. Preclinical validations of [18F]FPyPEGCBT-C(RGDfK): a 18F-labelled RGD peptide prepared by ligation of 2-cyanobenzothiazole and 1,2-aminothiol to image angiogenesis. Ejnmmi Radiopharm Chem. 2017;1 (1):16 https://doi.org/10.1186/s41181-016-0019-z.

Decristoforo C, Patt M. Are we "preparing" radiopharmaceuticals? Ejnmmi Radiopharm Chem. 2017;1(1):12 https://doi.org/10.1186/s41181-016-0011-7.

Domnanich KA, Müller C, Farkas R, Schmid RM, Ponsard B, Schibli R, et al. 44 Sc for labeling of DOTA- and NODAGAfunctionalized peptides: preclinical in vitro and in vivo investigations. Ejnmmi Radiopharm Chem. 2017;1(1):8 https://doi. org/10.1186/s41181-016-0013-5

Elsinga PH. Editorial - EJNMMI radiopharmacy and chemistry. Ejnmmi Radiopharm Chem. 2017;1 (1):2 https://doi.org/10.1186/ s41181-016-0006-4.

Eppard E, Pèrez-Malo M, Rösch F. Improved radiolabeling of DOTATOC with trivalent radiometals for clinical application by addition of ethanol. Ejnmmi Radiopharm Chem. 2017;1 (1):6 https://doi.org/10.1186/s41181-016-0010-8.

Jovalekic A, Koglin N, Mueller A, Stephens AW. New protein deposition tracers in the pipeline. Ejnmmi Radiopharm Chem. 2017;1(1):11 https://doi.org/10.1186/s41181-016-0015-3.

Koziorowski J, Behe M, Decristoforo C, Ballinger J, Elsinga P, Ferrari V, et al. Position paper on requirements for toxicological studies in the specific case of radiopharmaceuticals. Ejnmmi Radiopharm Chem. 2017;1 (1):1 https://doi.org/10.1186/s41181-016-0004-6.

Li S, Schmitz A, Lee H, Mach RH. Automation of the Radiosynthesis of six different ${ }^{18} \mathrm{~F}$-labeled radiotracers on the AllinOne. Ejnmmi Radiopharm Chem. 2017;1(1):15 https://doi.org/10.1186/s41181-016-0018-0.

Luurtsema G, Boersma HH, Schepers M, de Vries AMT, Maas B, Zijlma R, et al. Improved GMP-compliant multi-dose production and quality control of 6-[18F]fluoro-L-DOPA. Ejnmmi Radiopharm Chem. 2017;1 (1):7 https:/doi.org/10.1186/s41181-016-0009-1.

Meckel M, Bergmann R, Miederer M, Roesch F. Bone targeting compounds for radiotherapy and imaging: *me(III)-DOTA conjugates of bisphosphonic acid, pamidronic acid and zoledronic acid. Ejnmmi Radiopharm Chem. 2017;1 (1):14 https://doi.org/10.1186/s41181-016-0017-1.

Müller C, Vermeulen C, Köster U, Johnston K, Türler A, Schibli R, van der Meulen NP. Alpha-PET with terbium-149: evidence and perspectives for radiotheragnostics. Ejnmmi Radiopharm Chem. 2017;1 (1):5 https://doi.org/10.1186/s41181-016-0008-2.

Ooms M, Celen S, De Hoogt R, Lenaerts I, Liebregts J, Vanhoof G, et al. Striatal phosphodiesterase 10A availability is altered secondary to chronic changes in dopamine neurotransmission. Ejnmmi Radiopharm Chem. 2017;1(1):3 https://doi.org/10.1186/s41181-016-0005-5.

Seemann J, Waldron B, Parker D, Roesch F. DATATOC: a novel conjugate for kit-type ${ }^{68} \mathrm{Ga}$ labelling of TOC at ambient temperature. Ejnmmi Radiopharm Chem. 2017;1 (1):4 https://doi.org/10.1186/s41181-016-0007-3.

Zhang L, Villalobos A. Strategies to facilitate the discovery of novel CNS PET ligands. Ejnmmi Radiopharm Chem. 2017;1 (1):13 https://doi.org/10.1186/s41181-016-0016-2.

(c) The Author(s). 2018 Open Access This article is distributed under the terms of the Creative Commons Attribution 4.0 International License (http://creativecommons.org/licenses/by/4.0/), which permits unrestricted use, distribution, and reproduction in any medium, provided you give appropriate credit to the original author(s) and the source, provide a link to the Creative Commons license, and indicate if changes were made. 